\title{
COVID-19 pandemic: the 3R's (reduce, refine, and replace) of personal protective equipment (PPE) sustainability
}

\author{
Vivian Ip, MBChB, FRCA · Timur J. P. Özelsel, MD, DESA • \\ Rakesh V. Sondekoppam, MBBS, MD • Ban C. H. Tsui, MD, MSc, FRCPC
}

Received: 29 March 2020/Revised: 30 March 2020/Accepted: 31 March 2020/Published online: 14 April 2020

(c) Canadian Anesthesiologists' Society 2020

\section{To the Editor,}

Literature regarding the transmission risk of the coronavirus disease (COVID-19) to healthcare providers (HCP) is largely from early case reports/series or other clinical reports, both of which require critical appraisal. Timely recommendations for critical care and anesthesiology teams in managing COVID-19 patients are vital to the wellbeing of HCP. ${ }^{1}$ In light of a global shortage of personal protective equipment (PPE), drastic measures are being taken to preserve it. The 3R-mantra of sustainability (reduce, refine, and replace) not only applies to "green anesthesia" practice, ${ }^{2}$ but is also well-suited to PPE preservation.

Reduce. The first step is to eliminate all unnecessary use of PPE. Deferring all non-urgent surgeries preserves hospital resources and simultaneously reduces transmission of coronavirus. Rigorous screening measures for staff and visitors safeguards the hospital environment, and in turn also reduces the number of people in the hospital further contributing to infection containment. Indeed, this reduction strategy is similar to the current practice of public health policy across the globe of "social

V. Ip, MBChB, FRCA · T. J. P. Özelsel, MD, DESA

Department of Anesthesia and Pain Medicine, University of Alberta, Edmonton, AB, Canada

R. V. Sondekoppam, MBBS, MD

Department of Anesthesia, University of Iowa Hospital, Iowa City, IA, USA

B. C. H. Tsui, MD, MSc, FRCPC ( $\square)$.

Department of Anesthesiology, Perioperative, and Pain Medicine, Stanford University School of Medicine, Palo Alto, CA, USA

e-mail: bantsui@stanford.edu distancing", "shelter in place", and public gathering bans to avoid any non-essential contact in an attempt to "flatten" the pandemic curve and to prevent overwhelming the healthcare system.

Refine. Understanding the mode(s) of COVID-19 transmission is still evolving. The World Health Organization continues to recommend droplet and contact precautions for general care but airborne precautions for HCPs performing aerosol-generating medical procedures (AGMP) in COVID-19 patients. $^{\mathrm{A}}$ On the other hand, US Centers for Disease Control and Prevention (CDC) now recommends the use of respirator masks as part of the first line of protection of HCP caring for suspected COVID-19 patients. ${ }^{\mathrm{B}}$ In the presence of community spread, many centres in the US are already treating all untested surgical patients as presumed infectious. This could likely become the standard in all Canadian healthcare facilities, which will further drain PPE reserves. Modalities to increase airborne and contact/droplet PPE supplies other than procurement of currently used products will need to be explored. The need to refine the current culture of using disposable PPE to sustainable PPE solutions is essential for demand to meet supply-ideally, before a pandemic. Recently, the US Food and Drug Administration has

\footnotetext{
A World Health Organization. Modes of transmission of virus causing COVID-19: implications for IPC precaution recommendations. Available from URL: https://www.who.int/newsroom/commentaries/detail/modes-of-transmission-of-virus-causingcovid-19-implications-for-ipc-precaution-recommendations (accessed March 2020).

B Centers for Disease Control and Prevention. Interim Infection Prevention and Control Recommendations for Patients with Suspected or Confirmed Coronavirus Disease 2019 (COVID-19) in Healthcare Settings. Available from URL: https://www.cdc.gov/ coronavirus/2019-ncov/infection-control/control-recommendations. html (accessed March 2020).
} 
approved (in effect, a refine measure) reusable industrial respirators in clinical settings to address the acute shortage. ${ }^{\mathrm{C}}$ Decontamination and reclamation of used $\mathrm{PPE}^{\mathrm{D}}$ have also been widely disseminated; however, the safety of such practices is not well-supported with robust evidence. Although this presents a unique opportunity to preserve the limited supplies of PPE while reducing the environmental burden from their eventual disposal, the safety and efficacy of reusable PPE must be carefully studied prior to implementation and recommendation. More importantly, HCPs must also refine their skillset by understanding, simulating, and practicing donning and doffing both their disposable and reusable equipment properly and safely. ${ }^{3}$

Replace. Replacement of AGMP should be considered whenever feasible. In the midst of PPE shortage, regional anesthesia is an elegant and environmentally sustainable modality to circumvent the need of AGMP associated with general anesthesia. ${ }^{4}$

During this time of uncertainty, HCPs need to be extra vigilant in protecting themselves, including the likelihood of encountering asymptomatic COVID-19 patients. Despite PPE being a scarce resource, we should not compromise the safety for HCP by limiting use. Instead, we need to develop and implement ways to embrace sustainable solutions both for the current pandemic and for the future. Innovative ideas such as a $3 \mathrm{R}$ approach may be one such resource-conscious solution.
Conflicts of interest None.

Funding statement None.

Editorial responsibility This submission was handled by Dr. Hilary P. Grocott, Editor-in-Chief, Canadian Journal of Anesthesia.

\section{References}

1. Wax RS, Christian MD. Practical recommendations for critical care and anesthesiology teams caring for novel coronavirus (2019nCoV) patients. Can J Anesth 2020; DOI: https://doi.org/10.1007/ s12630-020-01591-x.

2. Özelsel TJ, Sondekoppam RV, Ip VH, Tsui BC. Re-defining the 3R's (reduce, refine, and replace) of sustainability to minimize the environmental impact of inhalational anesthetic agents. Can J Anesth 2019; 66: 249-54.

3. Lockhart SL, Naidu JJ, Badh CS, Duggan LV. Simulation as a tool for assessing and evolving your current personal protective equipment: lessons learned during the coronavirus disease (COVID-19) pandemic. Can J Anesth 2020; DOI: https://doi.org/ 10.1007/s12630-020-01638-z.

4. Lie SA, Wong SW, Wong LT, Wong TG, Chong SY. Practical considerations for performing regional anesthesia: lessons learned from the COVID-19 pandemic. Can J Anesth 2020; DOI: https:// doi.org/10.1007/s12630-020-01637-0.

Publisher's Note Springer Nature remains neutral with regard to jurisdictional claims in published maps and institutional affiliations.

\footnotetext{
${ }^{\mathrm{C}}$ U.S. Food and Drug Administration. Letter authorizing emergency use of all disposable filtering facepiece respirators. Available from URL: https://www.fda.gov/media/135763/download (accessed March 2020).

D U.S. Food and Drug Administration. Emergency Use Authorization (EUA) for the emergency use of the Battelle CCDS Critical Care Decontamination System ${ }^{\mathrm{TM}}$. Available from URL: http://www.fda. gov/media/136529/download (accessed March 2020).
} 